University of Nebraska - Lincoln

DigitalCommons@University of Nebraska - Lincoln

USDA Wildlife Services - Staff Publications

U.S. Department of Agriculture: Animal and Plant Health Inspection Service

2010

\title{
Response of Deer to Containment by a Poly-Mesh Fence for Mitigating Disease Outbreaks
}

\author{
Michael J. Lavelle \\ USDA/APHIS/WS National Wildlife Research Center, michael.j.lavelle@aphis.usda.gov \\ Justin W. Fischer \\ USDA/APHIS/WS National Wildlife Research Center, Justin.w.fischer@aphis.usda.gov \\ Scott E. Hygnstrom \\ University of Nebraska-Lincoln, shygnstrom1@unl.edu \\ Joshua J. White \\ South Dakota State University, Joshua.White@sdstate.edu \\ Aaron M. Hildreth \\ University of Nebraska-Lincoln
}

See next page for additional authors

Follow this and additional works at: https://digitalcommons.unl.edu/icwdm_usdanwrc

Part of the Life Sciences Commons

Lavelle, Michael J.; Fischer, Justin W.; Hygnstrom, Scott E.; White, Joshua J.; Hildreth, Aaron M.; Phillips, Gregory E.; and Vercauteren, Kurt C., "Response of Deer to Containment by a Poly-Mesh Fence for Mitigating Disease Outbreaks" (2010). USDA Wildlife Services - Staff Publications. 1272.

https://digitalcommons.unl.edu/icwdm_usdanwrc/1272

This Article is brought to you for free and open access by the U.S. Department of Agriculture: Animal and Plant Health Inspection Service at DigitalCommons@University of Nebraska - Lincoln. It has been accepted for inclusion in USDA Wildlife Services - Staff Publications by an authorized administrator of DigitalCommons@University of Nebraska - Lincoln. 


\section{Authors}

Michael J. Lavelle, Justin W. Fischer, Scott E. Hygnstrom, Joshua J. White, Aaron M. Hildreth, Gregory E. Phillips, and Kurt C. Vercauteren 


\title{
Response of Deer to Containment by a Poly-Mesh Fence for Mitigating Disease Outbreaks
}

MICHAEL J. LAVELLE, United States Department of Agriculture, Animal and Plant Health Inspection Service, Wildlife Services, National Wildlife Research Center, Fort Collins, CO 80521-2154, USA

JUSTIN W. FISCHER, United States Department of Agriculture, Animal and Plant Health Inspection Service, Wildlife Services, National Wildlife Research Center, Fort Collins, CO 80521-2154, USA

SCOTT E. HYGNSTROM, School of Natural Resources, University of Nebraska, Lincoln, NE 68583-0961, USA

JOSHUA J. WHITE, ${ }^{1}$ Nebraska Game and Parks Commission, Lincoln, NE 68503, USA

AARON M. HILDRETH, School of Natural Resources, University of Nebraska, Lincoln, NE 68583-0961, USA

GREGORY E. PHILLIPS, United States Department of Agriculture, Animal and Plant Health Inspection Service, Wildlife Services, National Wildlife Research Center, Fort Collins, CO 80521-2154, USA

KURT C. VERCAUTEREN, ${ }^{2}$ United States Department of Agriculture, Animal and Plant Health Inspection Service, Wildlife Services, National Wildlife Research Center, Fort Collins, CO 80521-2154, USA

\begin{abstract}
Rapidly deployable and effective methods are needed to contain free-ranging deer (Odocoileus spp.) during acute disease outbreaks. We evaluated efficacy of a 2.1-m-tall polypropylene mesh (poly-mesh) fence for containing $\geq 15$ free-ranging white-tailed deer $(O$. virginianus) within a 42 -ha area in eastern Nebraska, USA. We observed a $99 \%$ decrease in deer leaving the enclosure area after we installed fencing ( 1 deer jumped; 0.02 deer $/ \mathrm{hr}$ ) compared with prefence rates $(5.26 \mathrm{deer} / \mathrm{hr})$. However, 8 deer $(53 \%$ of censused population) escaped the enclosure during a census drive after our study. Poly-mesh fencing may be effective in temporarily containing free-ranging deer during minimally disruptive deer removal actions such as trapping or sharpshooting.
\end{abstract}

KEY WORDS containment, disease, fence, livestock, Odocoileus virginianus, white-tailed deer, wildlife damage management.

The livestock industry is a valuable component of United States agriculture, with an inventory valued $>$ US $\$ 100$ billion in 2008 (United States Census Bureau 2009). Livestock production remains vulnerable to the intentional or unintentional introduction and outbreak of disease because adequate biosecurity measures, naturally acquired immunity, and access to vaccines for foreign pathogens are lacking (Noah et al. 2002, Weller 2006). Thus, disease introduced into one livestock facility could spread rapidly within and among facilities, exacerbating economic losses (Blancou and Pearson 2003, Weller 2006, Rubira 2007). For example, an outbreak of foot-and-mouth disease (FMD) within one state such as Kansas, USA, could result in economic losses approaching US $\$ 1$ billion (Pendell et al. 2007).

Many diseases (e.g., FMD, brucellosis, bovine tuberculosis) are transmissible between livestock and free-ranging wildlife species and wildlife can act as both vectors and reservoirs (Bengis et al. 2002, Dudley and Woodford 2002, Ward et al. 2009). Presence of susceptible wildlife complicates disease management because wildlife may freely move across the landscape and interact with conspecifics and individuals of other species (Weller 2006, Ward et al. 2009).

White-tailed deer (Odocoileus virginianus), because of their widespread distribution (Côté et al. 2004), could play a major role in spreading disease within wild populations and domestic livestock. This species can be affected by a variety of diseases transmissible to livestock, including FMD

\footnotetext{
${ }^{1}$ Present address: 2203 Ingham Lake Road, Wallingford, IA 51365, USA

${ }^{2}$ E-mail: kurt.c.vercauteren@aphis.usda.gov
}

(McVicar et al. 1974). Emergence of an acute, highly contagious disease such as FMD involving deer in the United States would probably have devastating impacts on the livestock industry due to common use of space and resources (Dudley and Woodford 2002, Thomson et al. 2003, Ward et al. 2009).

Management techniques used to mitigate spread of diseases between wild and domestic herbivores vary considerably (e.g., depopulation, vaccination, containment). Depopulation methods, although locally effective, may be unpopular among many stakeholders (Dudley and Woodford 2002, Holsman and Smail 2006). Vaccinations can be effective but may be impractical or socially unacceptable for use in free-ranging wildlife (Bengis et al. 2002). Wildlife managers have historically used fences for managing certain diseases. For example, in an attempt to prevent cattle feverinfected ticks (Boophilus microplus) from being spread by white-tailed deer in Florida, USA, in the 1930s, wildlife managers constructed $128 \mathrm{~km}$ of 6-strand electrified barbedwire fence (McAtee 1939). Fences also have been reliable in controlling spread of FMD in Africa (Taylor and Martin 1987, Sutmoller et al. 1999, Thomson et al. 2003) and Lyme disease in the United States (Stafford 1993). Rapidly deployable techniques such as fencing are needed for containment and eradication of diseases spread via wildlife vectors from point-source occurrences (Jackson et al. 2009).

VerCauteren et al. (2006) reviewed literature on use of fencing to exclude deer and emphasized that a primary factor determining efficacy of a fence is level of motivation of targeted animals. For example, a high woven-wire mesh 
fence is necessary for impeding deer that are being pursued by humans (Falk et al. 1978), whereas a single-strand electric fence can be effective in protecting crops from deer (Hygnstrom and Craven 1988, Steger 1988). We conducted a preliminary study to evaluate efficacy of a rapidly deployable 2.1-m-high polypropylene mesh (poly-mesh) fence for containing white-tailed deer.

\section{STUDY AREA}

We conducted our study on the 3,385-ha DeSoto National Wildlife Refuge (NWR) in eastern Nebraska and western Iowa, USA $\left(41^{\circ} 31^{\prime} 27^{\prime \prime} \mathrm{N}, 96^{\circ} 0^{\prime} 58^{\prime \prime} \mathrm{W}\right)$ in late spring and early summer 2008. DeSoto NWR consisted of $41 \%$ bottomland forest, $27 \%$ grassland, $15 \%$ wetland, and $17 \%$ agricultural fields. Crops grown on DeSoto NWR included alfalfa (Medicago sativa), soybean (Glycine max), wheat (Triticum aestivum), and corn (Zea mays). Mean annual precipitation was $73.6 \mathrm{~cm}$, with mean annual maximum and minimum temperatures of $15.5^{\circ} \mathrm{C}$ and $5.3^{\circ} \mathrm{C}$, respectively (Pearce and Smith 1990). Estimated minimum deer population during the study was $722\left(25 / \mathrm{km}^{2}\right)$ based on January (2008) helicopter counts and data from fall (2007) deer harvest check stations on DeSoto NWR (G. M. Clements, University of Nebraska-Lincoln, unpublished data).

To conduct the evaluation, we selected a forested area within DeSoto NWR (Fig. 1) adjacent to crop fields (including wheat, soybean, and corn) that was a bedding area for deer (VerCauteren and Hygnstrom 1998, Walter et al. 2009). The 42-ha enclosure contained $65 \%$ eastern cottonwood (Populus deltoides) forest with an understory of primarily hackberry (Celtis occidentalis), mulberry (Morus rubra), and green ash (Fraxinus pennsylvanica). The forest ground layer was dominated by poison ivy (Rhus radicans) and common scouring rush (Equisetum hyemale). Grasses dominated by big bluestem (Andropogon gerardii) and smooth brome (Bromus inermis) made up 26\% of the enclosure. Crop fields made up the remaining $9 \%$ of the enclosure area (north and south sides combined). Further description of specific vegetation characteristics can be found in Walter et al. (2009).

\section{METHODS}

We evaluated a $2.3-\mathrm{m}$-tall high-strength mesh $\left(4.4-\mathrm{cm}^{2}\right)$ fence composed of ultraviolet-stable black polypropylene (Benner's Gardens Heavy Perimeter Deer Netting, Benner's Gardens, Phoenixville, PA). We installed the fence at $2.1 \mathrm{~m}$ in height, leaving an inward-facing $0.16-\mathrm{m}$ apron staked to the ground with $0.3-\mathrm{m}$ galvanized-steel stakes at $\geq 3$ locations between 3.0-m steel t-posts (e.g., GWP Industries Co., Ltd., Tianjin, China) installed every $6 \mathrm{~m}$ along the perimeter. We attached the fence to heavy-duty monofilament lines (200-kg breaking strength; one line at the top [2.1 m] and the second line $0.8 \mathrm{~m}$ from the ground) with a galvanized-steel hog ring every $1 \mathrm{~m}$ (Fig. 2). We attached monofilament lines to t-posts with heavy-duty plastic cable ties. To add rigidity to the fence, we installed H-braces constructed of closely spaced (3-m) vertical t-posts,

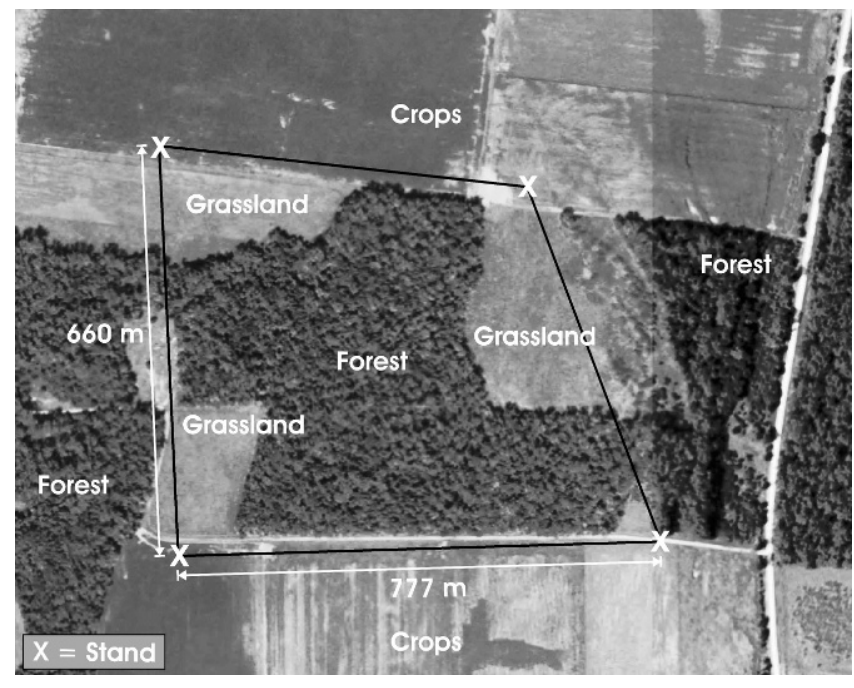

Figure 1. Layout of a 42-ha enclosure to evaluate efficacy of a polypropylene mesh fence for temporary containment of white-tailed deer in eastern Nebraska, USA, 2008.

connected by a horizontal t-post and diagonal wire strainers, at corners and every $75 \mathrm{~m}$ along the perimeter. We documented time and materials needed to construct the fence and incorporated labor costs of US\$10.00/hour. Overall costs did not include site-specific items such as removing trees or installing gates.

We visually documented evening deer movements out of the designated enclosure area during precontainment (4-24 Jun) and containment periods (25 Jun-17 Jul). Before the precontainment period, we installed $3.0-\mathrm{m}$ steel t-posts every $6 \mathrm{~m}$ along the entire perimeter of the enclosure. We anticipated northward and southward movements by deer to access adjacent crop fields; thus, we also attached the polymesh fence material on the east and west sections of the enclosure before the precontainment period. Installation of t-posts along the entire perimeter enabled observers to visualize the enclosure boundary for data collection during the precontainment period and reduced the time spent completing the enclosure and associated disturbance at the onset of the containment period. We completed the enclosure on 25 July by installing the poly-mesh fencing on north and south portions of the perimeter. While installing the fence, we worked as quickly and quietly as possible to minimize potential for driving animals out of the enclosure. To document potential effects of our disturbance during fence completion, observers monitored unfinished sections and documented deer movement as we progressed.

Before precontainment, we erected 4 4.6-m-tall tripod stands (StrongBuilt ${ }^{\circledR}$ Deluxe Magnum 14-foot Tripod Stand, StrongBuilt Inc., Waterproof, LA) topped with camouflaged blinds at the 4 corners of the enclosure. We conducted observations from 2 hours before sunset to 1 hour after on 5 evenings each week throughout the study. By observing from opposite corners, 2 individuals each evening were able to view the entire perimeter without overlapping coverage or double counting. Each successive evening, observers shifted to a blind that was unoccupied the 


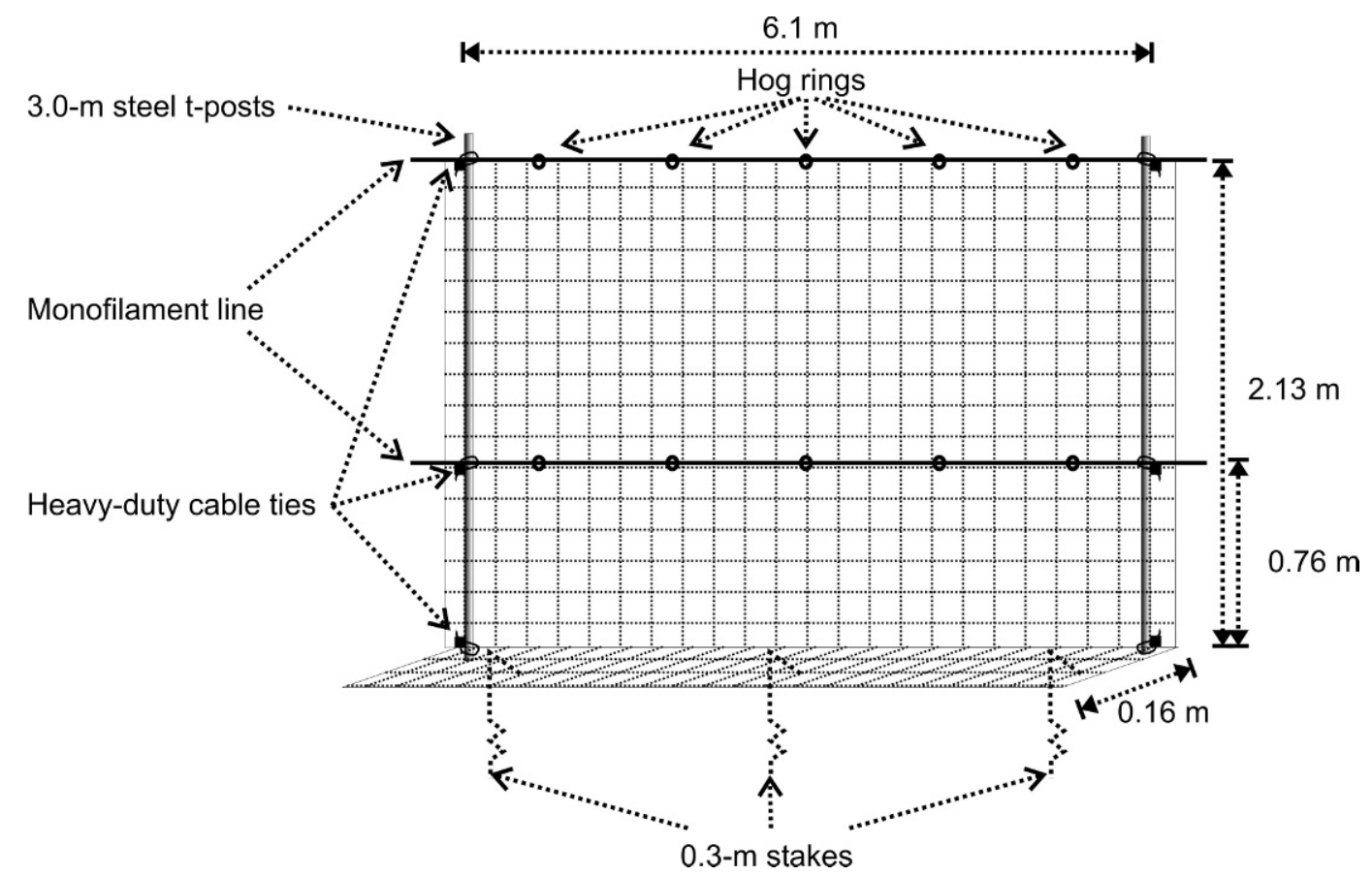

Figure 2. Components of temporary fence we used to construct experimental enclosure evaluated for containing white-tailed deer in eastern Nebraska, USA, 2008.

previous evening. We used $8 \times 32$-mm binoculars during daylight and forward-looking infrared thermal-imagers (PalmIR 250 Digital; Raytheon Commercial Infrared, Dallas, TX) after dark to observe deer.

We evaluated the fence using an unreplicated one-group pretest-posttest study design (Manly 1992). We monitored deer movement from inside to outside of the enclosure area during a precontainment period to provide a baseline measure of deer movement for comparison with movement data after the fence was completed (Guthrie 1987). We compared mean hourly outward movements across the enclosure's designated perimeter during the precontainment period $\left(\bar{x}_{p}\right.$ deer/hr) to mean hourly escapes during the containment period $\left(\bar{x}_{c}\right.$ deer/hr) as an index of efficacy of our fence. We weighted means by daily observation time. We also plotted daily movement rates to clarify trends in deer movement rates before and after the fence was completed.

To determine the minimum number of deer within the enclosure, we counted the maximum combined number of deer visible simultaneously during each evening observation period. Observers were in radio contact to ensure synchrony and independence of counts and that combined counts were maximums for each evening. We also conducted a deer drive after the containment period to evaluate fence performance when deer were being pursued to provide a second estimate of the number of deer remaining within the enclosure. We removed $120 \mathrm{~m}$ of perimeter fence at the southeastern corner and situated observers in stands on each side of the opening. We then used a crew of 32 individuals walking slowly from the north and west fencelines toward the opening to drive deer from the enclosure and count them.

To minimize disturbance during the precontainment and containment period, we limited our activity at the enclosure to routine observations, checking 2 water tanks once each week, and daily inspections of the perimeter to record any damage and maintain the fence. The Institutional Animal Care and Use Committees of the United States Department of Agriculture, Animal and Plant Health Inspection Service, Wildlife Services, National Wildlife Research Center (USDA APHIS WS NWRC; QA-1587) approved all procedures.

\section{RESULTS}

We monitored deer movements near the perimeter on 14 evenings during the precontainment period (mean daily observation time $=2.65 \mathrm{hr}$ ) and 16 evenings during the containment period (mean daily observation time $=2.73 \mathrm{hr}$ ). During the precontainment period, we monitored the perimeter for 37.1 hours and counted 195 outward perimeter crossings $\left(\bar{x}_{p}=5.26\right.$ deer/hr; Fig. 3). During the containment period, we documented only one escape from the enclosure (by an ad $\mathrm{F}$ that jumped over the fence) in 43.7 hours of observation $\left(\bar{x}_{c}=0.02 \mathrm{deer} / \mathrm{hr}\right)$, which corresponded to a $>99 \%$ reduction in outward movements by deer across the designated boundary of the enclosure after completion of the containment fence. From our radiocoordinated nightly counts, we know $\geq 15$ deer were contained (7 Jul).

While conducting daily inspections of the fence, we observed 5 deer run or jump into the fence, of which all were repelled upon impact without apparent harm to animal or fence. We also observed 4 occasions when deer stood erect on their hind legs and pushed on the fence with their front legs without escaping from the enclosure. Daily inspections revealed indirect evidence (i.e., broken cable ties at the top of the fence, tears in the poly-mesh, and bent fence posts) of 


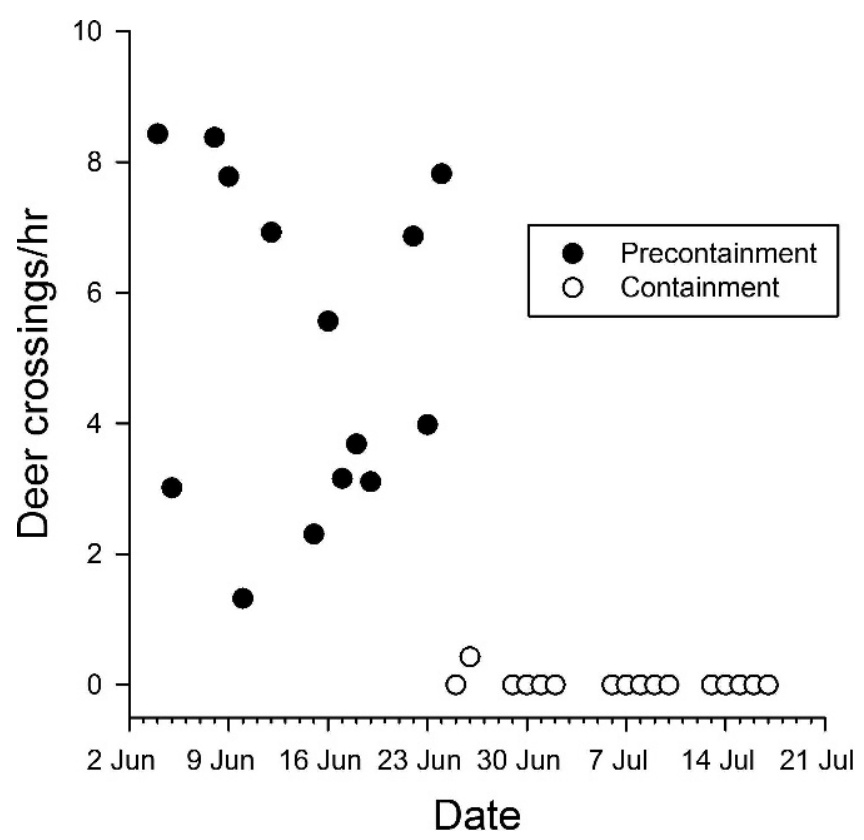

Figure 3. Mean hourly number of deer observed crossing the designated perimeter of an enclosure area before installation of a polypropylene mesh fence (precontainment) and after fence installation (containment) in eastern Nebraska, USA, 2008. Observations occurred from approximately 2 hours before sunset to 1 hour after sunset, and we only counted deer moving out of the enclosure area.

deer challenging the fence during both precontainment (7 occasions; east and west sections of fence only) and containment (17 occasions) periods. Damage to the fence was rarely substantial enough to suggest a perimeter crossing (during precontainment period) or an escape (during containment period) occurred, but we cannot dismiss the possibility that deer may have jumped the fence unobserved. However, on 2 occasions during the containment period we found tears in the fence approximately $0.5 \mathrm{~m}$ long, possibly large enough for a deer to pass through.

We did not obtain a reliable count of deer during the drive because none left the enclosure through the opening we created. However, motivation to escape from the enclosure was evidently high during the drive; as we observed 7 successful jumps of 11 attempts, one deer broke through the fence after jumping into and becoming entangled with it, and 3 deer were effectively repelled after running into the fence.

\section{DISCUSSION}

The poly-mesh fence design we tested in our preliminary study effectively minimized movements out of our enclosure area by free-ranging deer. Similar fencing of lower height $(1.8 \mathrm{~m})$ has proven effective for protecting specialty crops (e.g., truck farms, nurseries, orchards) from damage by deer in Wisconsin, USA (C. Lovell, USDA APHIS WS, personal communication). Although we did not know exact numbers of deer inside the enclosure area before or after the containment period, out of $\geq 15$ deer, we observed only one escape during evening observations throughout the containment period compared with routine movement out of the enclosure area to forage throughout the precontainment period. We assume deer returned to the enclosure area after foraging.

Although our study was strengthened by premanipulation monitoring (Guthrie 1987), it cannot provide conclusive evidence that the difference between periods was caused by the fence (lack of spatial control), and it does not justify broad inference to similar fence installations at other sites (lack of replication). However, the abrupt change coinciding with completion of the enclosure is strong evidence that the fence reduced deer crossings (Fig. 3). We believe alternative factors that might reduce deer crossing (e.g., changes in deer movements resulting from fawn maturation or from changes in forage plant phenology) would cause gradual, rather than abrupt, declines.

At the conclusion of the containment period, upon being pursued by humans, several animals repeatedly attempted to escape from the enclosure by jumping or running into the fence. Of these, 8 successfully breached the fence. Thus, as motivation increased, efficacy of the fence decreased. Our results emphasize that fence selection needs to account for expected levels of deer motivation produced by postfencing management actions to ensure adequate containment. Provisioning highly palatable feed and, if necessary, fresh water within the enclosure may further reduce motivation to escape and facilitate removal of deer via stealth means, like suppressed sharpshooting. As with all fences, we recommend routine inspection of the fence to maintain integrity.

Installation modifications may improve efficacy of the polymesh fence. Seven of 8 (88\%) observed deer-fence collisions resulted in deer being repelled. In contrast, only 5 of $13(38 \%)$ deer we observed trying to jump over the fence were deterred. Hence, the fence may not have been tall enough, or the monofilament used to support the top of the poly-mesh may have been too elastic to prevent pursued deer from jumping over the fence. For example, the one deer that jumped the fence during the containment period managed to exceed the height of the fence with only its head and neck; yet, elasticity of the top support allowed the momentum of the animal to carry it over. Elasticity of the fence top could be reduced by building corner and in-line $\mathrm{H}$-braces with wood posts (less robust and costly than used for woven-wire fence construction) and by using steel support wire rather than monofilament. In addition, taller $(2.4-\mathrm{m})$ and heavier-duty polymesh fence products that would probably perform better are now available. Woven-wire fence of 2.4-m height was found to prevent passage by even very highly motivated wild whitetailed deer in another fence evaluation (K. C. VerCauteren, USDA APHIS WS NWRC, unpublished report). In a disease response situation, poly-mesh fence could be erected more rapidly (and at a lower cost) by suspending it from trees where possible, but for research purposes (to be able to observe the fenceline) we used fence posts and made fencelines perfectly straight.

We were initially concerned that our fence installation activity would cause deer to leave the enclosure area, so we completed our most disruptive activities before the precontainment period. Causing deer to disperse also would be 
a concern in a disease outbreak situation in which dispersal would be counterproductive and unacceptable. Observers documented 2 deer leaving the enclosure area as we began work to complete installation of the fence, but they also saw 5 deer enter the enclosure while we worked. Although fencing activities might temporarily displace some deer, we suspect that deer in agricultural regions are accustomed to similar activities that, coupled with fidelity to preferred bedding sites, could minimize occurrence and duration of deer displacement.

Our attempt to count deer within the enclosure during the drive was unsuccessful, because no animals left through the opening. We found it difficult to flush deer from dense vegetation that made up most habitat within our enclosure. That 32 organized drivers could not direct deer through the opening in our 42-ha enclosure implies deer may not easily be driven, for example, toward shooters or into escape-proof pens for depopulation. McCullough (1979) described extreme day-to-day variability of deer behavior in response to drives within the enclosed George Reserve in southeastern Michigan, USA. Some days, most deer would move in the desired direction, well ahead of drivers; other days, few deer were observed due to hiding and sneaking, or deer would refuse to move in the desired direction ahead of the drive line and would instead run back through it. Thus, attempts at driving deer within a poly-mesh enclosure could cause unpredictable behavior, increase motivation to escape from the enclosure, and lead to otherwise preventable escapes.

Construction of the enclosure required nearly 38 -hour days for a crew of 8 nonprofessional fence installers (180 hr) and required only hand tools after driving fence posts with the bucket of a tractor. Other fences of similar height (e.g., woven-wire mesh) typically involve intensive site preparation, more substantial posts, and often require heavy equipment throughout installation. In addition, leveling ground where the fence was to be installed was unnecessary, as flexibility of the fence enabled us to follow the contour of the ground. Sloping terrain can reduce effective height of the fence and fence height should be increased on slopes to prevent deer on the high side from jumping out. Unit cost of labor and materials to construct the 42-ha enclosure was US $\$ 7.69 / \mathrm{m}$, considerably less than the cost of a typical deerproof fence (2.4-m woven-wire mesh, US\$15-20/m; VerCauteren et al. 2006). Multi-strand high-tensile wire or electrified poly-rope fences are comparably priced (US\$413/m installed; Seamans and VerCauteren 2006), although are typically less effective because their deterrence is reliant upon delivery of negative stimuli rather than presence of a physical barrier (McKillop and Sibley 1988). Unfortunately, an animal must receive the negative stimuli before crossing the fence allowing for retreat; thus, a calm investigation of the fence is needed, although it may not occur in a depopulation situation (McKillop and Sibley 1988).

\section{Management Implications}

Poly-mesh fencing could become a valuable component of emergency response to disease outbreaks or other applications requiring rapid, temporary containment or exclusion of deer. We envision poly-mesh fence used in containment applications where deer are not pursued and are thus unmotivated to escape an enclosure because enclosed areas are large enough to provide adequate security cover and forage, similar to conditions we evaluated. Such applications may constitute a rapid, but only preliminary, containment effort providing time to install more substantial fencing or enabling minimally disruptive deer removal techniques such as trapping or sharpshooting with suppressed rifles over bait. A high-stakes scenario involving FMD or other highly contagious, novel foreign animal diseases could justify follow-up installation of woven-wire fencing followed by aggressive lethal removal techniques such as drives or aerial gunning. We believe further evaluation of this concept is warranted to evaluate efficacy of design improvements such as taller, stronger poly-mesh, and more substantial support structures against deer under various levels of motivation.

\section{Acknowledgments}

We thank T. Ruby, G. Clements, D. Baasch, D. Walter, S. VanTassel, D. Virchow, T. Kinsell, C. Frost, and R. Woods for assistance in the field. Permission and assistance granted by DeSoto NWR personnel, especially L. Klemmick, M. Sheets, M. Cunard, M. Storm, S. Cooper, P. Magorian, and J. Havener, were invaluable. We also thank Associate Editor Messmer and anonymous reviewers for thoughtful comments and greatly improving the manuscript. Mention of companies or commercial products does not imply recommendation or endorsement by the USDA. Product names are mentioned solely to report factually on available data and to provide specific information.

\section{LITERATURE CITED}

Bengis, R. G., R. A. Kock, and J. Fischer. 2002. Infectious animal diseases: the wildlife/livestock interface. Revue Scientifique et Technique Office International des Epizooties 21:53-65.

Blancou, J., and J. E. Pearson. 2003. Bioterrorism and infectious animal diseases. Comparative Immunology, Microbiology and Infectious Diseases 26:431-443.

Côté, S. D., T. P. Rooney, J. Tremblay, C. Dussault, and D. M. Waller. 2004. Ecological impacts of deer overabundance. Annual Review of Ecological Systems 35:113-147.

Dudley, J. P., and M. H. Woodford. 2002. Bioweapons, bioterrorism and biodiversity: potential impacts of biological weapons attacks on agricultural and biological diversity. Revue Scientifique et Technique Office International des Epizooties 21:125-137.

Falk, N. W., H. B. Graves, and E. D. Bellis. 1978. Highway right-of-way fences as deer deterrents. Journal of Wildlife Management 42:646-650.

Guthrie, F. S. 1987. Guidelines for preparing and reviewing manuscripts based on field experiments with unreplicated treatments. Wildlife Society Bulletin 15:306.

Holsman, R. H., and R. A. Smail. 2006. Hunter effort and attitudes for the 2005 deer hunting season with relevant three-year trends. Dissertation, University of Wisconsin, Stevens Point, USA.

Hygnstrom, S. E., and S. R. Craven. 1988. Electric fences and commercial repellents for reducing deer damage in cornfields. Wildlife Society Bulletin 16:291-296.

Jackson, V. S., S. Huntley, A. Tomlinson, G. C. Smith, M. A. Taylor, and R. J. Delahay. 2009. Risk assessment and contingency planning for exotic disease introduction. Pages 169-185 in R. J. Delahay, G. C. Smith, and M. R. Hutchings, editors. Management of disease in wild mammals. Springer, Tokyo, Japan.

Manly, B. F. J. 1992. The design and analysis of research studies. Cambridge University Press, Cambridge, United Kingdom. 
McAtee, W. L. 1939. The electric fence in wildlife management. Journal of Wildlife Management 3:1-13.

McCullough, D. R. 1979. The George Reserve deer herd: population ecology of a K-selected species. University of Michigan Press, Ann Arbor, USA.

McKillop, I. G., and R. M. Sibley. 1988. Animal behaviour at electric fences and the implications for management. Mammal Review 18:91103.

McVicar, J. W., P. Sutmoller, D. H. Ferris, and C. H. Campbell. 1974. Foot-and-mouth disease in white-tailed deer: clinical signs and transmission in the laboratory. Annual Meeting of the U.S. Animal Health Association 78:169-180.

Noah, D. L., D. L. Noah, and H. R. Crowder. 2002. Biological terrorism against animals and humans: a brief review and primer for action. Veterinary Medicine Today: Zoonosis Update 221:40-43.

Pearce, E. A., and G. Smith. 1990. The times books world weather guide: updated edition. Times, New York, New York, USA.

Pendell, D. L., J. Leatherman, T. C. Schroeder, and G. S. Alward. 2007. The economic impacts of a foot-and-mouth disease outbreak: a regional analysis. Journal of Agricultural and Applied Economics 39:19-33.

Rubira, R. 2007. Disease control options for emergency animal diseasesnecessary yet sensitive elimination of disease. Veterinaria Italiana 43:333348.

Seamans, T. W., and K. C. VerCauteren. 2006. Evaluation of ElectroBraid $^{\mathrm{TM}}$ Fencing as a white-tailed deer barrier. Wildlife Society Bulletin $34: 8-15$.

Stafford, K. C. 1993. Reduced abundance of Ixodes scapularis (Acari: Ixodidae) with exclusion of deer by electric fencing. Journal of Medical Entomology 30:986-996.

Steger, R. E. 1988. Consider using electric powered fences for controlling animal damage. Proceedings of the Great Plains Wildlife Damage Control Workshop 8:215-216.
Sutmoller, P., G. R. Thomson, S. K. Hargreaves, C. M. Foggin, and E. C. Anderson. 1999. The foot-and-mouth disease risk posed by African buffalo within wildlife conservancies to the cattle industry of Zimbabwe. Preventive Veterinary Medicine 44:43-60.

Taylor, R. D., and R. B. Martin. 1987. Effects of veterinary fences on wildlife conservation in Zimbabwe. Environmental Management 11:327334.

Thomson, G. R., W. Vosloo, and A. D. S. Bastos. 2003. Foot and mouth disease in wildlife. Virus Research 91:145-161.

United States Census Bureau. 2009. The 2009 Statistical Abstract. $<$ http:// www.census.gov/compendia/statab/tables/09s0826.pdf $>$. Accessed 16 Nov 2009.

VerCauteren, K. C., and S. E. Hygnstrom. 1998. Effects of agricultural activities and hunting on home ranges of female white-tailed deer Journal of Wildlife Management 62:280-285.

VerCauteren, K. C., M. J. Lavelle, and S. Hygnstrom. 2006. Fences and deer-damage management: a review of designs and efficacy. Wildlife Society Bulletin 34:191-200.

Walter, W. D., K. C. VerCauteren, J. M. Gilsdorf, and S. E. Hygnstrom. 2009. Crop, native vegetation, and biofuels: response of white-tailed deer to changing management priorities. Journal of Wildlife Management 73:339-344.

Ward, A. I., K. C. VerCauteren, W. D. Walter, E. Gilot-Fromont, S. Rossi, G. Edwards-Jones, M. Lambert, M. R. Hutchings, and R. J. Delahay. 2009. Options for the control of disease 3: targeting the environment. Pages 147-168 in R. J. Delahay, G. C. Smith, and M. R. Hutchings, editors. Management of disease in wild mammals. Springer, Tokyo, Japan.

Weller, R. E. 2006. Risk of disease spread through bioterrorism. Veterinaria Italiana 42:351-367.

Associate Editor: Messmer. 